\title{
Cold shock and regulation of surface protein trafficking convey sensitization to inducers of stage differentiation in Trypanosoma brucei
}

\author{
Markus Engstler ${ }^{1}$ and Michael Boshart ${ }^{2}$ \\ Ludwig-Maximilians-Universität, Department Biologie I, Genetik, 80638 München, Germany
}

\begin{abstract}
Transmission of a protozoan parasite from a vertebrate to invertebrate host is accompanied by cellular differentiation. The signals from the environment that trigger the process are poorly understood. The model parasite Trypanosoma brucei proliferates in the mammalian bloodstream and in the tsetse fly. On ingestion by the tsetse, the trypanosome undergoes a rapid differentiation that is marked by replacement of the variant surface glycoprotein (VSG) coat with GPI-anchored EP and GPEET procyclins. Here we show that a cold shock of $\Delta T>15^{\circ} \mathrm{C}$ is sufficient to reversibly induce high-level expression of the insect stage-specific $\mathrm{EP}$ gene in the mammalian bloodstream stages of $T$. brucei. The 3'-UTR of the EP mRNA is necessary and sufficient for the increased expression. During cold shock, EP protein accumulates in the endosomal compartment in the proliferating, slender, bloodstream stage, whereas the EP is present on the plasma membrane in the quiescent, stumpy, bloodstream stage. Thus, there is a novel developmentally regulated cell surface access control mechanism for a GPI-anchored protein. In addition to inducing EP expression, cold shock results in the acquisition of sensitivity to micromolar concentrations of cis-aconitate and citrate by stumpy but not slender bloodstream forms. The cis-aconitate and citrate commit stumpy bloodstream cells to differentiation to the procyclic stage along with rapid initial proliferation. We propose a hierarchical model of three events that regulate differentiation after transmission to the tsetse: sensing the temperature change, surface access of a putative receptor, and sensing of a chemical cue.
\end{abstract}

[Keywords: GPI-anchor; post-transcriptional; procyclin; protein sorting; thermoregulation; tsetse]

Supplemental material is available at http://www.genesdev.org.

Received April 9, 2004; revised version accepted September 13, 2004.

Temperature is one of the major stresses that all organisms face. While heat shock has been extensively studied in bacteria and eukaryotes, mechanisms for the perception and transduction of low temperature signals have been discovered more recently (Aguilar et al. 2001; Johansson et al. 2002; Shinozaki et al. 2003). A sudden change in temperature may be a signal for sensing a specific environment for which a given temperature is characteristic. Parasites that shuttle between mammalian and arthropod hosts are exposed to environments that differ in many parameters including temperature (Fang and McCutchan 2002). Trypanosoma brucei is a protozoan flagellate that causes sleeping sickness in tropical Africa. The trypanosome life cycle is characterized by a succession of developmental stages adapted to the envi-

Correspondence.

${ }^{1}$ E-MAIL engstler@Irz.uni-muenchen.de; FAX 4989-2180-6160.

${ }^{2}$ E-MAIL boshart@Irz.uni-muenchen.de; FAX 4989-2180-63853.

Article and publication are at http://www.genesdev.org/cgi/doi/10.1101/ gad.323404. ronments in the mammalian host or the tsetse insect vector (Vickerman 1965; Vickerman et al. 1988). Within the bloodstream of the mammal, the proliferating stage of $T$. brucei has slender cell morphology. The differentiation of slender to quiescent, stumpy bloodstream stage occurs in response to cell density (Vassella et al. 1997; Seed and Wenck 2003). Stumpy trypanosomes are all set to respond to the environmental change accompanying uptake by the tsetse (Matthews and Gull 1994; Tasker et al. 2000).

Throughout the life cycle, densely packed surface coats consisting of GPI-anchored proteins cover the trypanosome plasma membrane (Cross 1987). The variant surface glycoprotein (VSG) coat of bloodstream-stage $T$. brucei is the paradigm for antigenic variation (Cross 1996; Barry and McCulloch 2001; Borst 2002). In the tsetse midgut, the trypanosomes express procyclins, a small family of EP (glu-pro repeat containing) and GPEET (gly-pro-glu-glu-thr repeat containing) proteins that are undetectable in bloodstream-stage trypano- 
somes (Overath et al. 1983; Roditi et al. 1989; Clayton et al. 1990; Roditi and Pearson 1990; Acosta-Serrano et al. 2001; Vassella et al. 2001a). Trypanosomes rapidly respond to transmission from a mammal to a tsetse by a cellular differentiation that includes radical changes in surface protein expression, metabolism, organelle function, and cytoskeletal architecture (Donelson et al. 1999; Clayton 2002; Gull 2003; McKean 2003; Matthews et al. 2004). The loss of VSG and the gain of procyclins are early hallmarks of the differentiation (Matthews et al. 2004).

The differentiation can be performed in culture and is particularly efficient and synchronous when millimolar concentrations of citrate or cis-aconitate are added (Brun and Schonenberger 1981; Overath et al. 1986; Ziegelbauer et al. 1990; Hunt et al. 1994). Little is known about the molecules and mechanisms that trigger the differentiation (Matthews 1999; Matthews et al. 2004). However, it is likely that the control of the differentiation involves novel mechanisms as gene expression of trypanosomes is almost exclusively regulated at the post-transcriptional level (Clayton 2002).

In this study, we show that cold shock alone induces the expression of EP procyclins by a post-transcriptional mechanism and at the same time sensitizes trypanosomes to chemical inducers of development. The sensitization is coincident with a developmentally regulated change in surface protein trafficking.

\section{Results}

Cold shock is sufficient to induce expression of EP procyclin in $\mathrm{T}$. brucei bloodstream stages

Trypanosomes leave the homeothermic environment of their mammalian hosts as a tsetse feeds. To investigate any role of temperature in control of differentiation, we determined the expression of procyclic-specific genes in bloodstream stages in response to decreased tempera- tures. The synthesis of the major surface protein of the insect stage, EP procyclin, was found to be strongly induced in the bloodstream stages upon incubation at $20^{\circ} \mathrm{C}$. The kinetics of EP expression was analyzed by flow cytometry after incubation of stumpy bloodstream trypanosomes at $20^{\circ} \mathrm{C}$ and was compared with a standard in vitro differentiation protocol $16 \mathrm{mM}$ cis-aconitate at $27^{\circ} \mathrm{C}$ ) (Ziegelbauer et al. 1990; Rolin et al. 1993; Matthews and Gull 1994; Vassella and Boshart 1996). Both treatments resulted in identical kinetics of EP surface expression (Fig. 1A). In control cultures incubated at $27^{\circ} \mathrm{C}$ in the absence of cis-aconitate, no EP surface expression was detectable by flow cytometry within $24 \mathrm{~h}$, as reported before (Sbicego et al. 1999). Thus, a temperature shift of more than $15^{\circ} \mathrm{C}$ was sufficient to induce EP synthesis to the level of differentiating cells.

To monitor cold-inducible EP expression in single living cells, an EP1:GFP hybrid gene was targeted to replace an endogenous EP1 gene of T. brucei MITat 1.2 (construct pG- $\Delta$ LII.EG) (see Tables 1,2 ). When grown at $37^{\circ} \mathrm{C}$, only background fluorescence was detectable. A shift of the culture temperature to $18^{\circ} \mathrm{C}$ raised EP1:GFP fluorescence in 5-7 h (Fig. 1B). An incubation of trypanosomes at $18^{\circ} \mathrm{C}$ in buffer containing glucose (TDB) resulted in the same temperature-dependent induction of EP1:GFP, excluding any role of the cell culture medium. GFP expression was quantified by photon counting of segmented microscopic images to ensure that the distribution of EP1:GFP expression in the cell population was homogeneous $(<9 \%$ standard deviation), confirming the synchrony seen in Figure 1A. To rule out reporter-genespecific temperature responses, isogenic cell lines having a luciferase reporter replacing the EP1 gene at the EP1 procyclin locus were generated (construct pG- $\Delta$ LII.Luc) (see Tables 1, 2). Three independent transgenic clones were tested for luciferase activity. Lysates from cells cold-shocked for $6 \mathrm{~h}$ revealed a 65-fold augmented luciferase activity when compared to lysates from cells
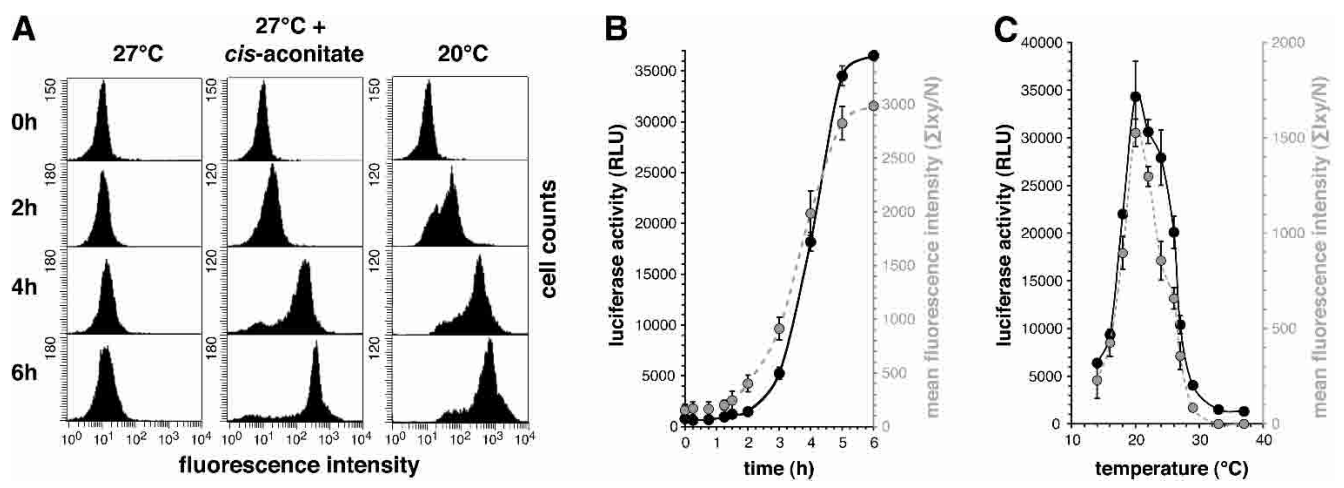

Figure 1. Kinetics and properties of cold shock induction of EP expression. (A) Detection of EP on the cell surface of trypanosomes by flow cytometry (mAb TRBP/247). Stumpy bloodstream cells were incubated at $27^{\circ} \mathrm{C}$ in the absence (left panel) or presence (middle panel) of $6 \mathrm{mM}$ cis-aconitate or at $20^{\circ} \mathrm{C}$ (right panel). (B) Cold shock induces reporter gene expression from the EP1 expression site. Transgenic trypanosomes carrying a luciferase gene (construct pG- $\Delta$ LII.Luc) or an EP1:GFP fusion gene (construct pG- $\Delta$ LII.EG) within the EP1 expression site were incubated at $18^{\circ} \mathrm{C}$. At the indicated time points, luciferase activity was measured by luminometry $(\bullet)$, and EP1:GFP expression was quantified by fluorescence microscopy (ㅇ). $(C)$ Temperature profile of reporter gene induction. Cell lines expessing luciferase $(\bullet)$ or EP1:GFP (ㅇ) from the EP1 locus (see $B$ ) were incubated for $16 \mathrm{~h}$ at the indicated temperatures. 
Engstler and Boshart

Table 1. Genotypes of recombinant $\mathrm{T}$. brucei cell lines generated in this study

\begin{tabular}{|c|c|c|}
\hline $\begin{array}{l}\text { Targeting } \\
\text { construct }\end{array}$ & $\begin{array}{l}\text { T. brucei } \\
\text { host strain }\end{array}$ & $\begin{array}{l}\text { Genotype of } \\
\text { recombinants }\end{array}$ \\
\hline pG- $\Delta$ LII.EG & MITat 1.2 & $\Delta e p::(G F P:: E P 1 \Delta L I I) N E O$ \\
\hline pG- $\Delta$ LII.Luc & MITat 1.2 & $\Delta e p:: L U C \Delta L I I N E O$ \\
\hline pL20-wt.EG & MITat 1.2 & $R D N A::(G F P:: E P 1) B L E$ \\
\hline pL20- $\Delta$ LII.EG & MITat 1.2 & $R D N A::(G F P:: E P 1 \Delta L I I) B L E$ \\
\hline pL82- $\Delta$ LII.EG & MITat $1.213-90^{\mathrm{b}}$ & T7POL TETR NEO HYG RDNA::(GFP::EP1DLII $\left.{ }^{T i}\right)$ BLE \\
\hline pTub- $\Delta$ LII.EG & MITat 1.2 & TUB::(GFP::EP1 $\triangle L I I) B L E$ \\
\hline pL82.EG & MITat $1.213-90^{\mathrm{b}}$ & T7POL TETR NEO HYG RDNA::(GFP::EP1 $\left.{ }^{T i}\right)$ BLE \\
\hline pL20.Luc & MITat 1.2 & $R D N A:: L U C B L E$ \\
\hline pG- $\Delta 164 . E G$ & MITat 1.2 & $\Delta e p::(G F P:: E P 1 \Delta 164) B L E$ \\
\hline pL20- $\Delta$ UTR.EG & MITat 1.2 & $R D N A::(G F P:: E P 1 \Delta U T R) B L E$ \\
\hline pL20- $\Delta$ UTR.Luc & MITat 1.2 & $R D N A:: L U C \Delta U T R B L E$ \\
\hline pG- $\Delta$ LII.EG & AnTat1.1 & $\Delta e p::(G F P:: E P 1 \Delta L I I) N E O$ \\
\hline pTR.EG & AnTat1.1, MITat 1.2 & $R R N A::(G F P:: E P 1) H Y G$ \\
\hline pES221.EG & MITat 1.2 & VSG221::(GFP::EP1) NEO \\
\hline pES221.E & MITat 1.2 & VSG221::EP1 NEO \\
\hline pL82.E & AnTat $1.190-13^{\mathrm{c}}$ & TETR T7POL NEO HYG RDNA::EP1 ${ }^{T i} B L E$ \\
\hline
\end{tabular}

${ }^{\text {a}}$ Fusion genes are given in parentheses.

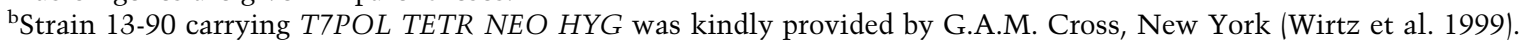

${ }^{\mathrm{c}}$ Miriam van den Bogaard and Mark Günzel (this lab).

grown at $37^{\circ} \mathrm{C}$ (Fig. 1B). The kinetics of cold shock induction of luciferase activity was not only comparable to that of EP1:GFP fluorescence but also to the kinetics of endogenous EP1 procyclin expression in wild-type cells (Fig. 1A). The temperature optimum for both reporters was between $19^{\circ} \mathrm{C}$ and $22^{\circ} \mathrm{C}$, with a peak at $20^{\circ} \mathrm{C}$ (Fig. 1C). A sharp decline in expression of both reporters occurred at higher and lower temperatures. Thus, EP expression in T. brucei bloodstream stages is responsive within a strictly defined temperature range.

The EP1 3'-UTR contains a cold-shock-responsive sequence

To confirm the gene specificity of the cold shock response and to identify regulatory elements conferring cold shock sensitivity, we further dissected the EP1 expression site. To test whether the genomic environment of the EP1 gene locus was a prerequisite for cold shock sensitivity, EP1:GFP, together with a procyclin promoter and corresponding $5^{\prime}$ and $3^{\prime}$ flanks, was targeted to a transcriptionally silent rDNA spacer in the $T$. brucei genome (Fig. 2A; Table 2, constructs pL20-wt.EG and pL20- $\Delta$ LII.EG). Quantitative fluorescence microscopy revealed at least 60 -fold elevated GFP-fluorescence at $20^{\circ} \mathrm{C}$ when compared to $37^{\circ} \mathrm{C}$, similar to the endogenous locus. Next, the influence of the promoter was tested by exchanging the procyclin promoter with a strong, tetracycline-responsive phage T7 promoter (Fig. 2A; Table 2, construct pL82-ALII.EG). Cold shock induced a strong increase in EP1:GFP expression, ultimately leading to cell death $12-16 \mathrm{~h}$ post-cold-shock (data not shown). This experiment suggested that the procyclin promoter was not essential for cold shock response. This was further confirmed by inserting promoterless EP1:GFP into the tubulin locus, where the intrinsic tubulin (pol II-)

Table 2. Description of constructs and mapping of a cold-shock response sequence to the EP1 3'-UTR

\begin{tabular}{|c|c|c|c|c|c|c|}
\hline Construct & $\begin{array}{l}\text { Genomic } \\
\text { locus }\end{array}$ & Promoter & 5'-UTR & $\begin{array}{l}\text { Reporter } \\
\text { gene }\end{array}$ & 3'-UTR & $\begin{array}{c}\text { Cold-shock } \\
\text { induction factor }\end{array}$ \\
\hline pL20-wt.EG & rDNA spacer & $G P E E T^{T I}$ & GPEET & EP1:GFP & EP1 & 64.5 \\
\hline pG- $\Delta 164 . E G$ & $E P$ & EP1 & EP1 & EP1:GFP & $E P 1 \Delta 1-164$ & 62 \\
\hline pG- $\Delta$ LII.EG & $E P$ & EP1 & EP1 & EP1:GFP & EP1D101-173 & 61 \\
\hline pG- $\Delta$ LII.Luc & $E P$ & EP1 & EP1 & luciferase & EP1D101-173 & 65.1 \\
\hline pL20- $\Delta$ LII.EG & rDNA spacer & $G P E E T^{T I}$ & GPEET & $E P 1: G F P$ & EP1D101-173 & 63.7 \\
\hline pL82- $\Delta$ LII.EG & rDNA spacer & $T 7^{T I}$ & GPEET & EP1:GFP & EP1D101-173 & $>30^{\mathrm{b}}$ \\
\hline pTub- $\Delta$ LII.EG & tubulin & Read through & aldolase & EP1:GFP & EP1D101-173 & 59.8 \\
\hline pL20-AUTR.EG & rDNA spacer & $G P E E T^{T I}$ & GPEET & EP1:GFP & $E P 1 \Delta 1-297$ & 3.2 \\
\hline pL20-AUTR.Luc & rDNA spacer & $G P E E T^{T I}$ & GPEET & luciferase & $E P 1 \Delta l-297$ & 5.5 \\
\hline pES221-EG & vsg221 ES & $V S G$ & actin & EP1:GFP & actin & 4.7 \\
\hline pL82-EG & rDNA spacer & $T 7^{T I}$ & GPEET & EP1:GFP & aldolase 1-177 & 5.9 \\
\hline pL20-Luc & rDNA spacer & $G P E E T^{T I}$ & GPEET & luciferase & aldolase 1-177 & 6.3 \\
\hline pTR-EG & rDNA promoter & $r D N A$ & EP1 & EP1-GFP & tubulin & 3.7 \\
\hline
\end{tabular}

${ }^{a}$ Quotient of reporter expression measured at $20^{\circ} \mathrm{C}$ and $37^{\circ} \mathrm{C}$. A table with the underlying data is provided as Supplemental Material.

${ }^{b}$ Due to the high basal expression level, a cold-shock-induced elevation of EP1:GFP of $>30$-fold is lethal for the cells. 

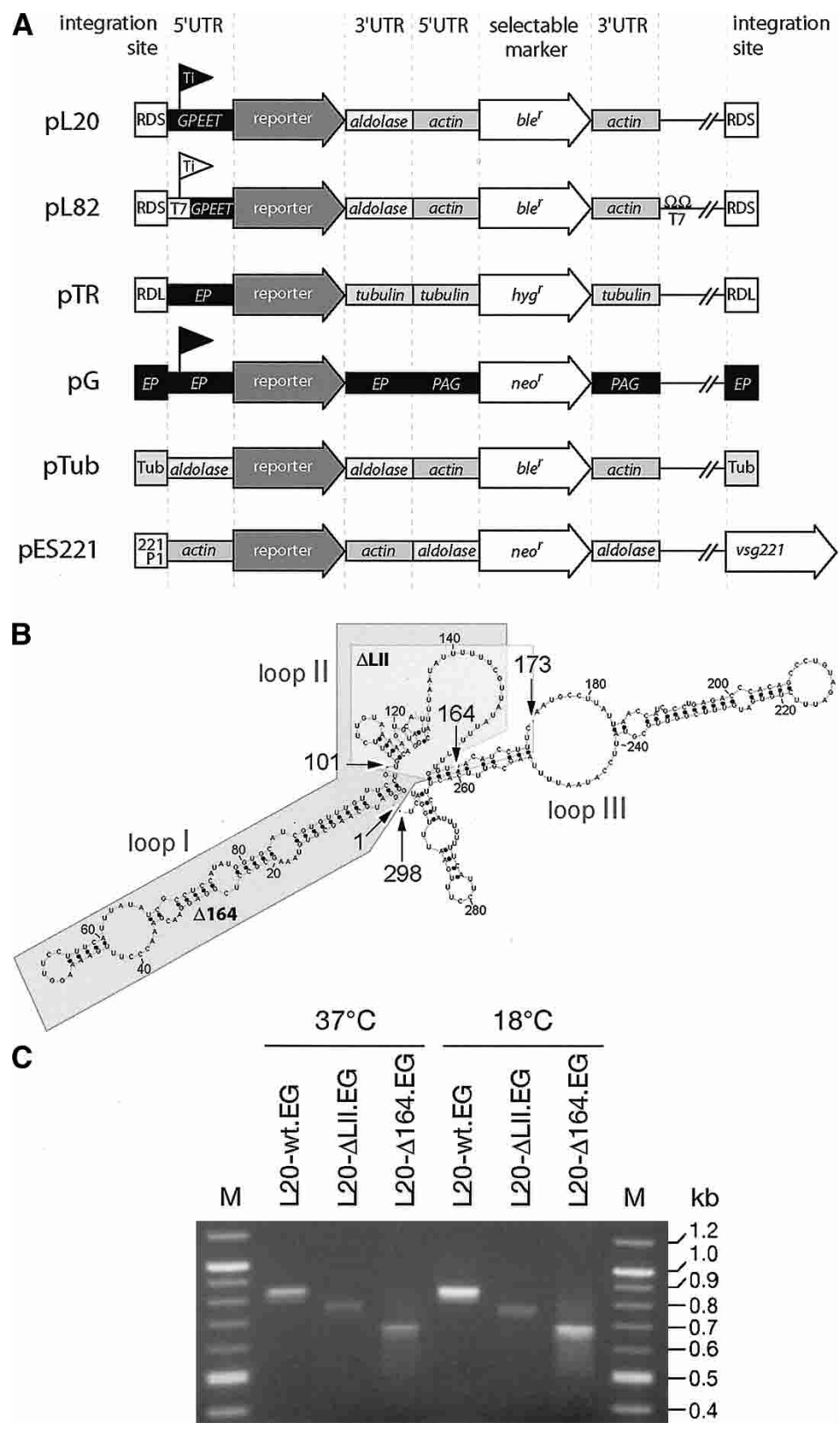

Figure 2. (A) Structure of the basic constructs used in this work: pL20 (Wirtz et al. 1998), pL82 (Wirtz et al. 1999), pTR (Xong et al. 1998), pG (Furger et al. 1997), pTub (Wirtz et al. 1994), pES221 (Muñoz-Jordán et al. 1996; M. Engstler and G.A.M. Cross, unpubl.). (Ti) Tetracycline-inducible; (RDS) rDNA spacer; (RDL) rDNA locus; $(\Omega)$ T7 terminator; (PAG) procyclin-associated gene; (Tub) tubulin array; (221P1) VSG221-pseudogene I. (B) Predicted secondary structure of the EP1 3'-UTR. For calculation the M-fold software (http://www. bioinfo.rpi.edu/applications/mfold) was used with constraints derived from Drozdz and Clayton (1999). Independent loops are labeled I-III, and the endpoints of relevant deletion mutants are marked by arrows and by large font size. Deletions $\Delta$ LII and $\Delta 164$ are shaded. $(C)$ RT-PCR of EP1:GFP mRNAs in recombinant T. brucei cell lines. Sequences between the GFP reporter and the cognate EP1 polyadenylation site were amplified (for details see Supplemental Material). The expected sizes of the PCR products are $850 \mathrm{bp}$ (L20-wt.EG), $777 \mathrm{bp}$

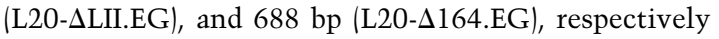
(M, size marker; 100-bp ladder). The cDNA samples were shown free of contaminating genomic DNA by an independent PCR reaction. transcription confers a moderate expression level (Fig. 2A; Table 2, construct pTub-ALII.EG). Again, a 60-fold augmented EP1:GFP fluorescence was seen at $20^{\circ} \mathrm{C}$. In construct pTub- $\Delta$ LII.EG the EP1 5 '-UTR was replaced with an aldolase $5^{\prime}$-UTR. Thus, a specific role of the 5 '-UTR in cold shock sensing could also be excluded.

The above observations suggested that a cold-shocksensitive sequence was located within either the procyclin 3'-UTR or the intergenic region (IGR). The predicted secondary structure of the EP1 3 '-UTR is shown in Figure 2B. Cold induction conferred by the complete UTR/ IGR was then compared with that of deletion mutants 1-164 and 101-173 of the EP1 3'-UTR (Furger et al. 1997; Schurch et al. 1997). Both showed a 60- to 65-fold increase in reporter activity at $20^{\circ} \mathrm{C}$ (Table 2; Supplemental Material), indicating that out of the 297 nucleotides defining the EP1 3'-UTR, nucleotides 1-173 were not essential for cold shock sensing. We have verified that transcripts from the three constructs pL20-wt.EG, pL20$\Delta$ LII.EG, and pL20- $\Delta 164$.EG in cells grown at $37^{\circ} \mathrm{C}$ or at $20^{\circ} \mathrm{C}$ all include the UTR sequence up to the cognate polyadenylation site of EP (Fig. 2C). Deletion of the entire 3'-UTR (nucleotides 1-297), leaving only the polyadenylation site and intergenic region, reduced the inducibility of reporter gene expression below the response of three control constructs (Table 2; Supplemental Material). We noticed a moderate three- to sixfold cold induction mediated by the 3 '-UTRs of three constitutively expressed mRNAs: tubulin and actin and aldolase (Biebinger et al. 1996). It is probable that this observation reflects a general RNA stabilization at $20^{\circ} \mathrm{C}$. A global effect on transcription or elongation seems less likely, 
Engstler and Boshart

but was not ruled out. Therefore, the most conservative estimate of EP-specific cold induction is 10- to 20-fold. In summary, we have mapped a specific cold shock response sequence between positions 174 and 297 of the EP1 3'UTR. For two of the cell lines (L20-wt.EG and L20$\Delta$ 164.EG) we have estimated the stability of the transcripts at $37^{\circ} \mathrm{C}$ and at $20^{\circ} \mathrm{C}$. The mRNA levels were followed after transcription inhibition with actinomycin $\mathrm{D}$, using semiquantitative multiplex RT-PCR (data available as Supplemental Material). A significantly delayed decay at $20^{\circ} \mathrm{C}$ showed that at least part of the EP-specific cold induction operates at the level of mRNA stability.

\section{Surface routing of EP1 is developmentally regulated between the slender and the stumpy bloodstream stage of $\mathrm{T}$. brucei}

Proliferating slender bloodstream-stage trypanosomes differentiate to quiescent, stumpy bloodstream stage cells that are preadapted to further developmental progression within the insect vector (Vickerman 1985; Vassella et al. 1997; Matthews 1999). By comparing cold inducibility of EP synthesis in these two life-cycle stages, we made a surprising observation. In both, slender and stumpy wild-type AnTat1.1 trypanosomes, coldshock-induced EP1 expression was seen by Northern and Western blot analysis (Fig. 3A). However, only stumpy trypanosomes routed procyclin to the cell surface, whereas the EP was retained intracellularly in slender forms (Fig. 3D). To investigate this stage-specific routing in live cells, we targeted EP1:GFP to the EP1 locus of the pleomorphic strain AnTat 1.1 (construct pG- $\Delta$ LII.EG). Pure slender and stumpy populations of the transgenic clones were incubated on HMI-9 agarose plates at $20^{\circ} \mathrm{C}$ for $12 \mathrm{~h}$. Cold-shocked stumpy trypanosomes evenly incorporated EP1:GFP into the VSG surface coat (Fig. 3E, st), as did wild-type stumpy cells with endogenous EP (cf. Fig. 3D, st). Proliferating slender cells also showed strong EP1:GFP expression at $20^{\circ} \mathrm{C}$; however, GFP fluorescence was completely absent from the cell surface. The signal was restricted to an intracellular compartment, located between the flagellar pocket and the nucleus (Fig. 3E, sl). As control, a transgenic AnTat 1.1 line was generated that expresses EP1:GFP from the ribosomal promoter re-
Figure 3. Developmentally regulated routing of EP1 and EP1:GFP in bloodstream-stage trypanosomes. Pure AnTat1.1 slender (sl) and stumpy (st) bloodstream populations and established isogenic procyclic cultures (pcf) were compared by Northern and Western blot analyses. $(A)$ Wild type. $(B)$ Transgenic line with EP1:GFP replacing the EP1 gene (construct pG- $\Delta$ LII.EG). (C) Transgenic line expressing EP1:GFP from the ribosomal promoter region (construct pTR.EG). Cells were incubated for $14 \mathrm{~h}$ at $37^{\circ} \mathrm{C}$ or $20^{\circ} \mathrm{C}$ as indicated or at $27^{\circ} \mathrm{C}$ for procyclic cultures. Normalized quantitative expression data for EP and GFP are given below the corresponding bands. A $\beta$-tubulin hybridization probe and an anti-PFR antibody were used for normalization of Northern and Western blots, respectively. The asterisk indicates that fivefold less total RNA or cell equivalents was loaded to the PCF lane. Three-channel fluorescence imaging of selected samples (as indicated) of panels $A-C$ is shown in $D-F$, respectively. (Blue) DAPI staining of the nuclear and mitochondrial (kinetoplast) DNA; (red) AnTat1.1 VSG immunofluorescence, outlining the cell surface; (green) EP immunofluorescence in wild-type cells $(D)$ or EP1:GFP autofluorescence $(E, F)$. Yellow/orange color indicates colocalization of red and green fluorescence emission of nonequalized channels. Maximum intensity projections of 3D stacks are shown, and the red channel of slender cells was processed using a morphological gradient filter to facilitate the visualization of intracellular staining in 3D images. The right-side cell is a representation without red channel information. The flagellar pocket is indicated by arrowheads. All images are representative subregions of larger wide-field data sets displaying $>20$ cells each. The phenotypic homogeneity of slender and stumpy populations with respect to surface routing of EP or EP1:GFP was $99 \% \pm 1 \%(n>1000$ cells analyzed).

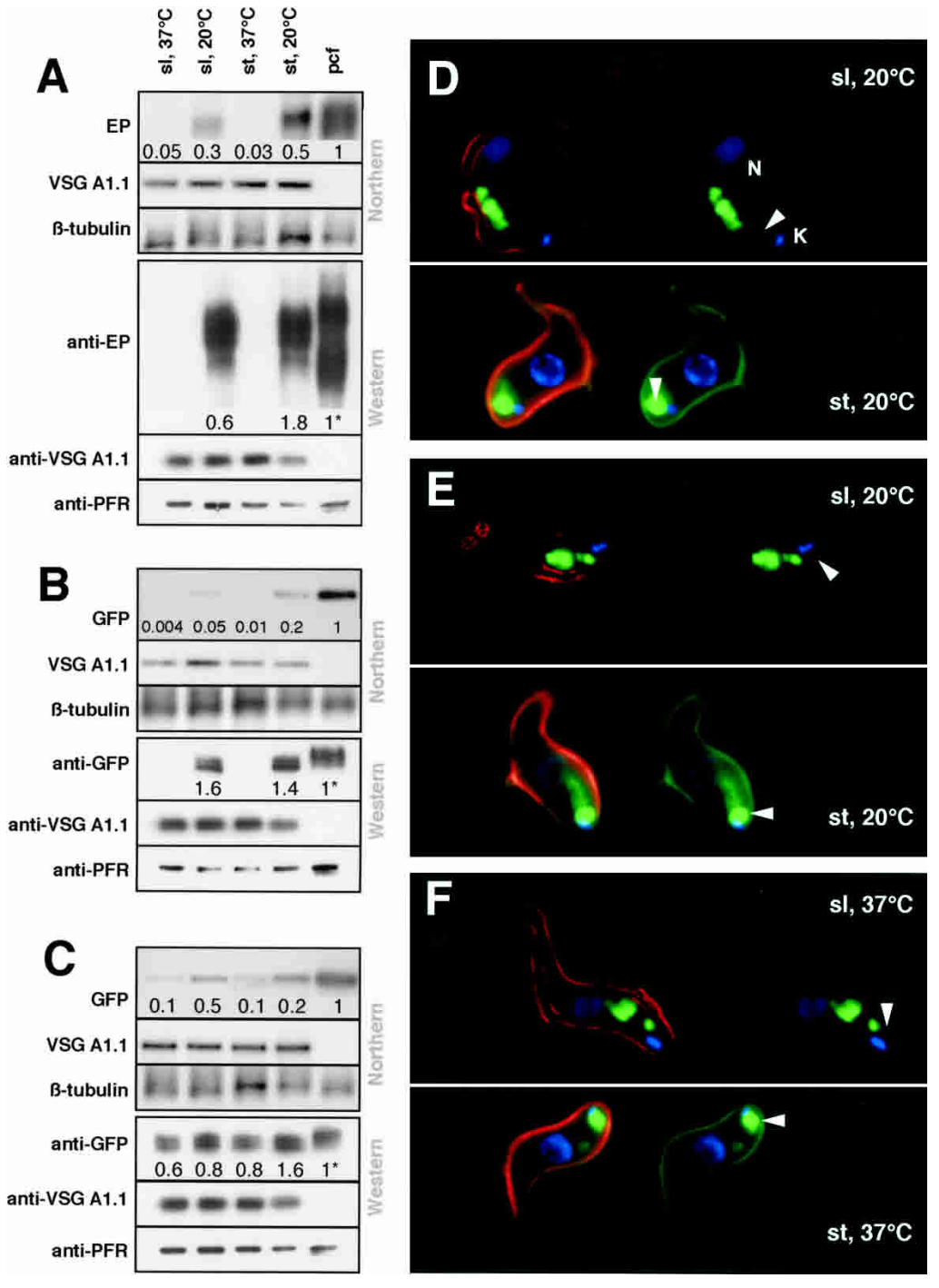


gion (construct pTR.EG) where transcription is not subject to developmental regulation. In slender trypanosomes of this pTR.EG transgenic line, EP1:GFP was found in the same intracellular compartment as in coldshocked slender cells expressing EP1:GFP from the EP1 locus (Fig. 3F, sl). Furthermore, stumpy cells of the same line routed EP1:GFP to the cell surface at $37^{\circ} \mathrm{C}($ Fig. $3 \mathrm{~F}$, st). The routing of EP1 and EP1:GFP was developmentally regulated between the slender and stumpy stage and not temperature-dependent. Therefore, we conclude that cell cycle arrest and/or differentiation to the stumpy stage per se are required for access of EP1 or EP1:GFP to the cell surface.

To facilitate the identification of the subcellular structures, which accumulate EP1 and EP1:GFP in slender trypanosomes, we used transgenic lines derived from strain MITat 1.2 that has the dual advantage of being more amenable to in vitro cultivation and having lost the ability to differentiate to the stumpy stage. The EP1 gene and the corresponding EP1:GFP chimera were tar-
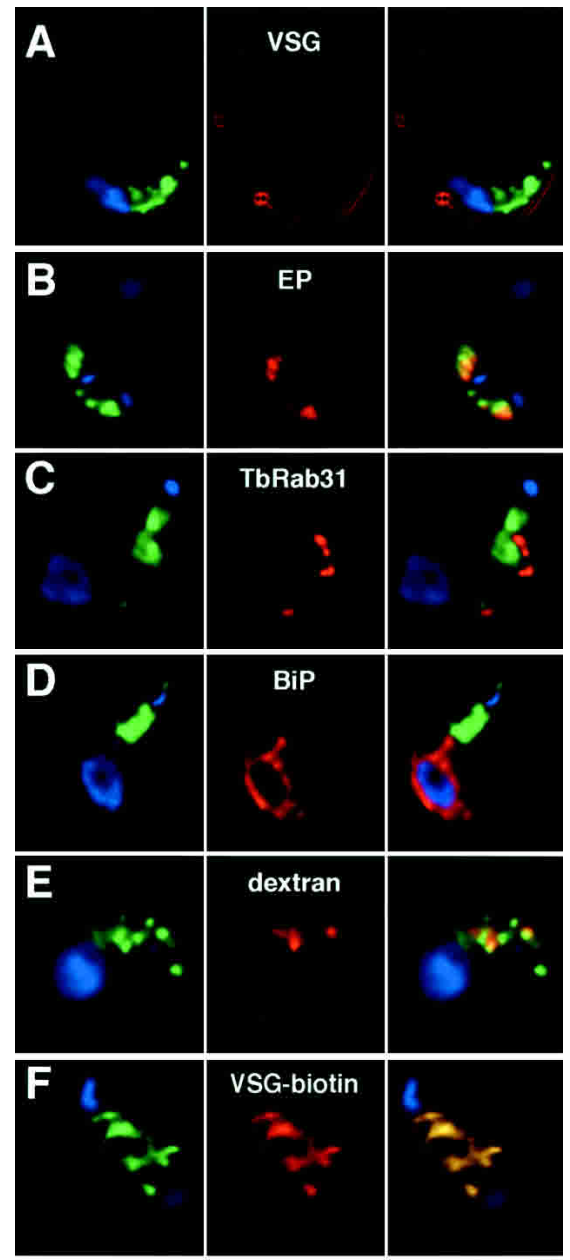

VSG-biotin
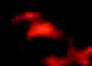

$7 x^{2}$
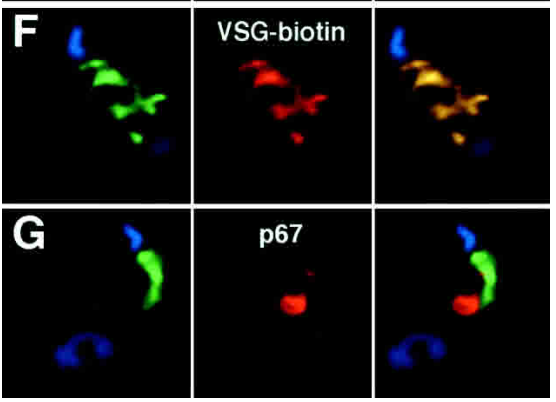

p67

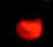

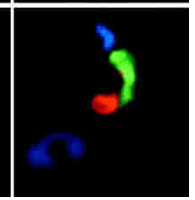

geted to the VSG221 expression site of strain MITat 1.2, an ectopic chromosomal context that guarantees high level expression (constructs pES221.E and pES221.EG, respectively) (see Table 1). The intracellular localization of ectopically expressed EP1 and EP1:GFP was identical to that observed in AnTat 1.1 slender trypanosomes, excluding misrouting due to the GFP tag, even at an elevated expression level (data not shown). Neither endogenous EP1 (Fig. 4B, middle panel) nor EP1:GFP (Fig. 4, left panels) appeared within the surface coat of monomorphic slender cells. The fluorescently stained intracellular compartment was characterized by quantitative 3D colocalization analysis (Engstler et al. 2004). Only $4 \%$ of EP1:GFP colocalized with the ER chaperone BiP (Fig. 4D; Bangs et al. 1993). A Golgi accumulation of EP1:GFP was excluded since EP1:GFP did not colocalize with the Golgi-specific marker TbRAB31 (Fig. 4C; Field et al. 2000). Interestingly, 39\% of the GFP fluorescence colocalized with a fluid-phase endocytosis marker (dextran), suggesting a routing of EP1:GFP through the endocytic compartment (Fig. 4E). This was strongly supported by the finding that EP1:GFP almost quantitatively $190 \%-$ 95\%) colocalized with internalized VSG, recycling to the cell surface via endocytic compartments (Fig. 4F; Grunfelder et al. 2002, 2003; Engstler et al. 2004). Only a minor colocalization $(<2 \%)$ was obtained with the lysosomal membrane protein p67 (Fig. 4G; Kelley et al. 1999; Alexander et al. 2002). We conclude from the minimal fraction of EP1:GFP in ER and Golgi that EP1:GFP is rapidly transported through the secretory pathway of slender T. brucei. The protein, however, never gains access to the cell surface but accumulates within the endosomal system, which extends from the flagellar pocket region to the lysosome. To estimate the turnover of EP1:GFP in this compartment, protein synthesis was

Figure 4. Subcellular localization of EP1:GFP in bloodstreamstage T. brucei MITat1.2. All images represent a single confocal plane extracted from digitally deconvolved multichannel 3D image data sets that were acquired using the same batch of fixed and permeabilized cells expressing EP1:GFP from the VSG221 expression site (pES221.EG). The left column images show an intensity merge of green EP1:GFP and blue DAPI fluorescence. The middle column shows the intracellular localization of markers, and the right column images show a merge of the three channels. (A) Cell surface staining by rabbit polyclonal VSG221 antiserum (1:1000) (red). (B) Endogenous EP (and EP1:GFP) detected by a mouse monoclonal EP antibody (1:500) (red). (C) The ER chaperone $\mathrm{BiP}$ detected by polyclonal rabbit anti-BiP (antibody courtesy of Jay Bangs, Madison; 1:500). (D) The Golgi marker TbRAB31 detected by rabbit anti-TbRAB31 (antibody courtesy of Mark Field, London; 1:200). (E) Endocytosed Alexa Fluor 594 conjugated dextran (see Materials and Methods). $(F)$ Endocytosed biotinylated VSG (see Materials and Methods) detected with Alexa Fluor 594-conjugated streptavidin (Molecular Probes). $(G)$ The lysosome visualized with a mouse monoclonal antibody directed against the lysosomal membrane protein p67 (antibody courtesy of David Alexander and Jay Bangs, Wiscon$\sin ; 1: 1000)$. Alexa Fluor 594-conjugated goat anti-rabbit second antibody $(1: 2000)(A, C, D)$ or CY3-conjugated sheep anti-mouse second antibody $(1: 1000)(B, G)$ was used. 
blocked with cycloheximide, and the decrease in GFP fluorescence emission was quantified by microscopy of individual live cells. The estimated half-life of total intracellular EP1:GFP was $3.5 \mathrm{~h}$. This means that EP:GFP is sufficiently stable in order to cycle through the endocytic machinery many times $(>20 \times)$ before eventual degradation (see Engstler et al. 2004).

\section{Cold-induced procyclin expression can be uncoupled from the commitment to differentiate to the insect stage}

Flow cytometry of a transgenic stumpy line carrying a cold-shock-inducible EP1:GFP gene at the EP1 locus showed identical initial induction kinetics of EP1:GFP surface fluorescence at $20^{\circ} \mathrm{C}$ or under standard in vitro differentiation conditions $\left(27^{\circ} \mathrm{C}, 6 \mathrm{mM}\right.$ cis-aconitate $)$ (Fig. 5A, cf. Fig. 1A for endogenous EP). Incubation was then continued at $20^{\circ} \mathrm{C}$ for $100 \mathrm{~h}$ in the presence and absence of cis-aconitate, and fluorescence intensity was measured every hour using an automated fluorescence reader. In the presence of cis-aconitate, a steep increase in total fluorescence intensity per culture volume was observed after $12 \mathrm{~h}$. This fluorescence gain was due to the onset of cellular proliferation (Fig. 5B). Proliferation did not resume during continuous culture at $20^{\circ} \mathrm{C}$ without cis-aconitate and only a minor increase in fluorescence due to increased cell size and a small number of spontaneously differentiating cells was noted. Although all cells in the population continued to express EP1:GFP on the surface after $80 \mathrm{~h}$, a very high fraction $(95 \% \pm 3.4 \%)$ of cells with one nucleus and one kinetoplast ( $1 \mathrm{~K} 1 \mathrm{~N}$, marking $\mathrm{G}_{1}$-phase cells) indicated that cold treatment alone did not induce the rapid proliferation associated with differentiation to the procylic insect stage. In addition, immunofluorescence showed that these cells did not express an early procyclic marker, the cytoskeleton-associated calpain-related protein CAP5.5 (Matthews and Gull 1994; Hendriks et al. 2000), whereas cis-aconitate-treated cells were all positive for this marker after $12 \mathrm{~h}$. We conclude that EP expression per se is not sufficient to release stumpy trypanosomes from cell cycle arrest, and therefore EP surface expression can be uncoupled from the commitment to differentiation.

Consistent with an absence of commitment, the coldinduced EP expression was fully reversible. Logarithmically growing slender bloodstream trypanosomes, harboring EP1:GFP within the EP1 locus (pG- $\Delta$ LII.EG), were incubated at $20^{\circ} \mathrm{C}$ for $3 \mathrm{~d}$. After $24 \mathrm{~h}$ the cells showed peak EP1:GFP expression and elevated population doubling times, probably because of the cultivation at $20^{\circ} \mathrm{C}$. No obvious cell death was observed. After $72 \mathrm{~h}$, the temperature was shifted back to $37^{\circ} \mathrm{C}$. Within $24 \mathrm{~h}$ the amount of detectable EP1:GFP dropped to $20 \%$. With the onset of cellular proliferation, the expression vanished completely (Fig. 6A). In an analogous experiment, stumpy cells were subjected to $20^{\circ} \mathrm{C}$ for $24 \mathrm{~h}$. Then the temperature was shifted back to $37^{\circ} \mathrm{C}$ for another $24 \mathrm{~h}$ (Fig. 6B). The viability of the trypanosomes was monitored throughout the experiment using motility as marker. Quantitative fluorescence microscopy revealed that EP1:GFP expression peaked $8 \mathrm{~h}$ post-cold-shock. Interestingly, incubation at $37^{\circ} \mathrm{C}$ for $12 \mathrm{~h}$ was sufficient to almost completely revoke the temperature-dependent EP1 expression, indicating immediate cessation of synthesis. Given the different half-life of VSG ( $33 \mathrm{~h}$ ) (Seyfang et al. 1990) and EP:GFP (3.5 h; see above), this resulted in rapid disappearance of GFP-fluorescence from the stumpy cell surface coat. This result was independent from the length of cold exposure, tested in a range from 6 to $24 \mathrm{~h}$.

During differentiation, the expression of EP and shedding of the VSG coat are coordinate events. Therefore, stumpy cells were incubated at $20^{\circ} \mathrm{C}$ in the presence or absence of cis-aconitate and analyzed by quantitative fluorescence microscopy for surface expression of VSG and EP1:GFP. In agreement with published data (Ziegelbauer et al. 1993), the VSG coat was shed within $12 \mathrm{~h}$ in the presence of cis-aconitate (Fig. 6C). Cold shock alone did not result in a significant loss of surface VSG (Fig. $6 \mathrm{D})$, although a reduced VSG transcription rate has been observed earlier upon cold treatment (Clayton et al. 1990). We conclude that the cold-shock-induced EP synthesis is reversible in both bloodstream stages and that
Figure 5. Cold shock alone is not sufficient to promote developmental progression. (A) Analysis of the initial EP1:GFP surface expression kinetics by flow cytometry. Aliquots of a transgenic AnTat1.1 stumpy population carrying the EP1:GFP gene within the EP1 expression site (construct pG- $\Delta$ LII. EG) were incubated at $27^{\circ} \mathrm{C}$ in the absence (left panel) or presence (middle panel) of $6 \mathrm{mM}$ cis-aconitate, and at $20^{\circ} \mathrm{C}$ (right panel). (B) The resuming cellular proliferation and differentiation of the cold-shocked EP1:GFP-expressing cells was further monitored for $100 \mathrm{~h}$ in the presence and absence of $6 \mathrm{mM}$ cis-aconitate at $20^{\circ} \mathrm{C}$ (note arrow from $A$ to $B$ ). Total fluorescence per culture volume was measured in intervals of $1 \mathrm{~h}$ (mean fluorescence intensity of six parallels \pm standard deviation; $0, \bullet)$ using an automated fluorescence reader.
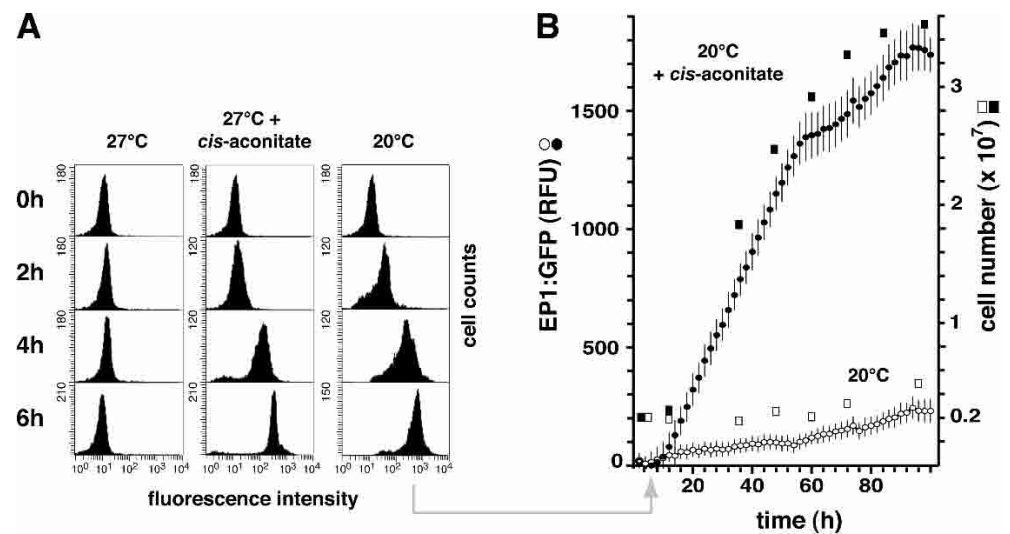
In parallel, cell numbers were counted $(\square, \mathbf{\square})$. Cis-aconitate induces cellular proliferation and differentiation to the procyclic insect stage $(\bullet,-\mathbf{v})$. In the absence of cis-aconitate $(0, \square)$, only a minor fluorescence gain and almost no cellular proliferation can be observed. 
VSG shedding and cold-induced EP expression and surface routing are not necessarily synchronized events. Hence, EP expression can be uncoupled from the commitment to differentiate to the procyclic stage.

\section{Cold shock renders stumpy-stage trypanosomes hypersensitive to cis-aconitate}

The surprising cold-induced changes in gene expression and protein trafficking led us to determine the dose response of cis-aconitate in cold-shocked $T$. brucei. Stumpy cells, harboring EP1:GFP within the EP1 expression site (construct pG- $\Delta$ LII.EG), were incubated for $16 \mathrm{~h}$ at $37^{\circ} \mathrm{C}$ (Fig. $7 \mathrm{~A}$ ) or $20^{\circ} \mathrm{C}$ (Fig. $7 \mathrm{~B}$ ). Then cis-aconitate was added in a range of concentrations from $1 \mu \mathrm{M}$ to 6 $\mathrm{mM}$, and trypanosomes were kept at $27^{\circ} \mathrm{C}$ for $7 \mathrm{~d}$. The morphology, viability, proliferation, and expression of EP1:GFP were monitored in intervals of $24 \mathrm{~h}$. Proliferation is a definitive marker of procyclic differentiation when the initial bloodstream-stage population is homogeneous stumpy. Trypanosomes that had been preincubated at $37^{\circ} \mathrm{C}$ were not responsive to cis-aconitate concentrations below $1 \mathrm{mM}$ (Fig. 7A). In contrast, coldshocked trypanosomes showed an enhanced sensitivity toward cis-aconitate down to the micromolar range. These cells differentiated to procyclic morphology (data not shown) and proliferated (Fig. 7B). High sensitivity to cis-aconitate was accompanied by an initial populationdoubling time down to $\sim 5 \mathrm{~h}$. Later, proliferation gradually slowed down, leveling at a population doubling time of 9-12 h. The time lag until onset of rapid proliferation correlated with the concentration of cis-aconitate. In a range between $200 \mu \mathrm{M}$ and $6 \mathrm{mM}$ of cis-aconitate this onset was immediate. At lower concentrations the onset of proliferation was delayed; however, the fast initial growth rate after the lag was independent of the cisaconitate concentration. The treatment of cold-shocked cells with citrate instead of cis-aconitate resulted in very similar data (data not shown). When the tricarboxylic stereoisomers trans-aconitate $(10 \mu \mathrm{M}$ to $6 \mathrm{mM})$ or isocitrate were added to the cultures as controls, no induction of proliferation was observed, confirming the inducer specificity. A direct or indirect role of EP surface expression for the increase in cis-aconitate sensitivity was excluded by experiments with a transgenic AnTat1.1 line that constitutively expresses EP1 (construct pL82.E targeted to a rDNA spacer region of the genome). No increase of cis-aconitate sensitivity was observed in stumpy cells of that line in the absence of a cold shock (Fig. 7C), although the EP1 surface expression levels were similar $( \pm 15 \%)$ to cold-shocked wild-type cells. A control population of the pL82.E transgenic line incubated at $20^{\circ} \mathrm{C}$ was sensitive to cis-aconitate (data not shown). Thus, EP1 surface expression is neither directly
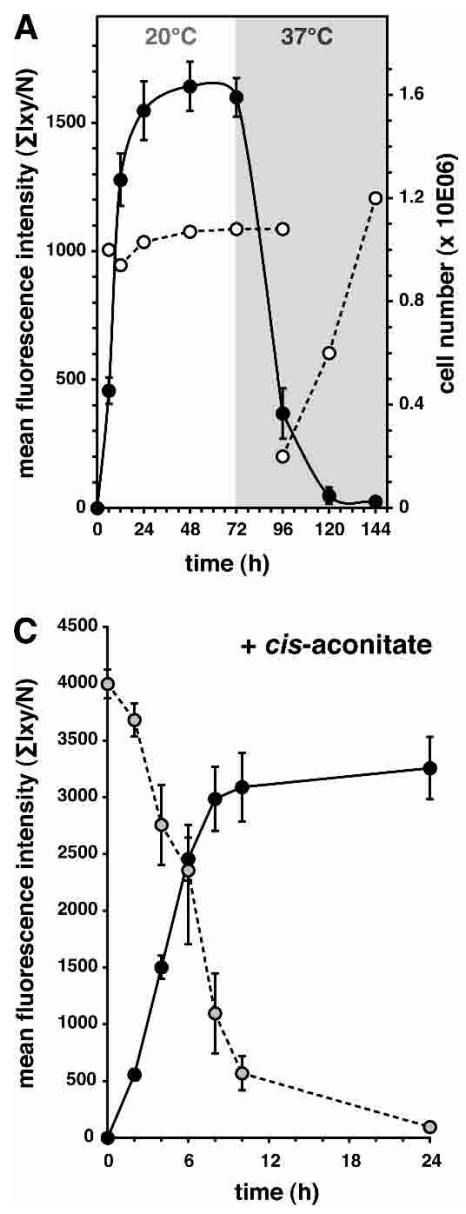
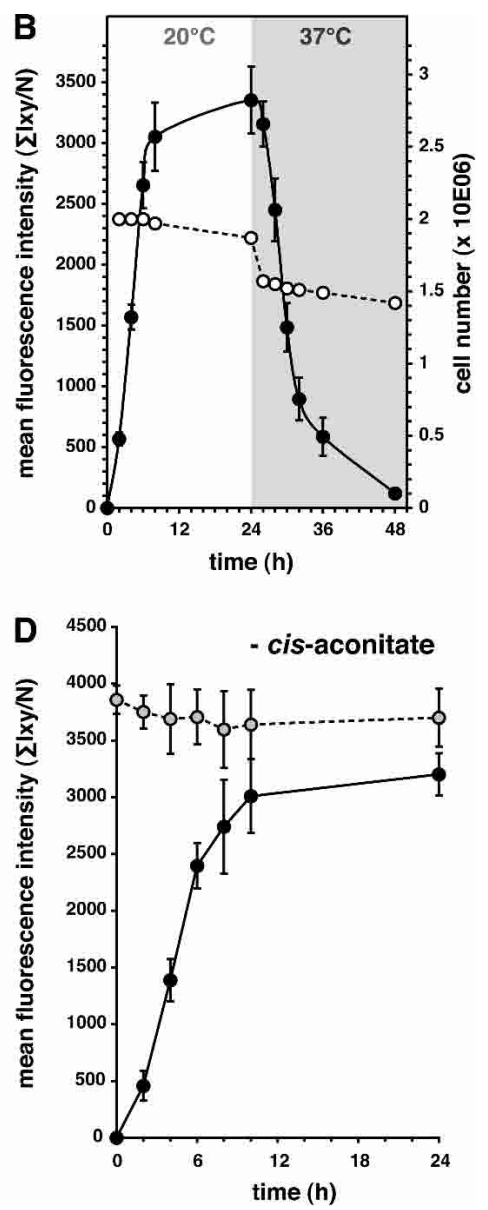

Figure 6. Cold shock induction of EP procyclin synthesis is reversible in slender and stumpy bloodstream stages and is not accompanied by VSG coat release. $(A)$ Slender AnTat1.1 cells, carrying EP1:GFP within the EP1 expression site (construct pG- $\Delta$ LII.EG), were cultivated at $20^{\circ} \mathrm{C}$ with a daily change of cell culture medium. After $72 \mathrm{~h}$, cultivation was continued at $37^{\circ} \mathrm{C}$ and cells were diluted fivefold with fresh medium. $(B)$ Stumpy populations derived from the same transgenic clone as in $A$ were incubated for $24 \mathrm{~h}$ at $20^{\circ} \mathrm{C}$ and then transferred to $37^{\circ} \mathrm{C}$. The EP1:GFP expression $(\bullet)$ was measured by quantitative fluorescence microscopy, and cell proliferation $(0)$ was monitored by cell counting. $(C, D)$ Induction of EP1:GFP synthesis $(\bullet)$ and loss of VSG (ㅇ) were monitored in transgenic stumpy cells, cultivated for $24 \mathrm{~h}$ in the presence $(C)$ or absence $(D)$ of 6 $\mathrm{mM}$ cis-aconitate at $20^{\circ} \mathrm{C}$. EP1:GFP-specific and VSGspecific fluorescence were quantified with a CCD camera. 
Engstler and Boshart

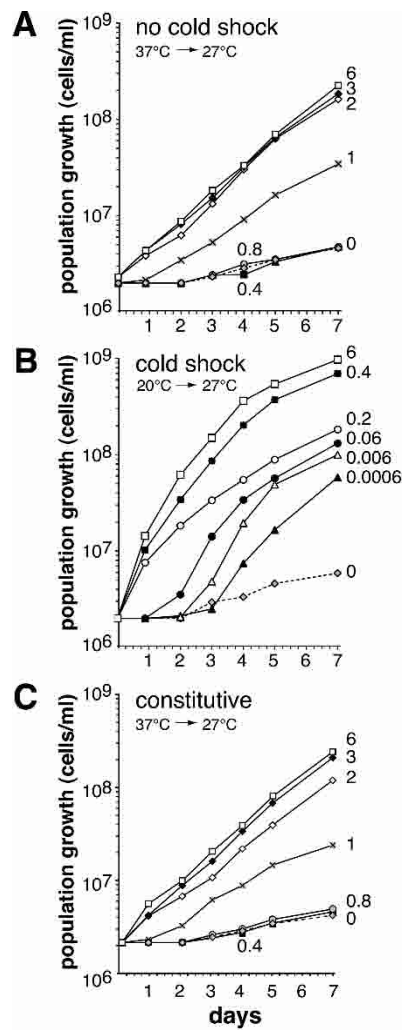

Figure 7. Cold shock renders T. brucei hypersensitive to cisaconitate. (A) Wild-type stumpy cells of strain AnTat1.1 were cultivated for $7 \mathrm{~d}$ at $27^{\circ} \mathrm{C}$ in DTM medium in the presence of various concentrations of cis-aconitate $(0-6 \mathrm{mM}$; see numbers in graph). To provide logarithmic growth conditions, the cell density was kept below $7 \times 10^{6}$ per milliter by dilution with fresh culture medium. The population growth was calculated as cell density multiplied by the cumulative dilution factors. At cis-aconitate concentrations below $1 \mathrm{mM}$, virtually no cellular proliferation was seen. (B) Cells were cold-shocked at $20^{\circ} \mathrm{C}$ for $16 \mathrm{~h}$, and then treated exactly as in $A$. Growth data for cisaconitate concentrations $\geq 0.8 \mathrm{mM}$ were identical to the $6 \mathrm{mM}$ data points (data not shown). (C) Transgenic AnTat1.1 stumpy cells, constitutively expressing EP1 from the rDNA spacer (construct pL82.E) were treated as in $A$. Expression of EP was monitored after 1, 3, and $7 \mathrm{~d}$ by immunofluorescence microscopy, revealing that irrespective of the amount of cis-aconitate added, all cells were expressing EP on the cell surface.

nor indirectly involved in the cold-induced change of cis-aconitate sensitivity.

\section{Discussion}

Environmental cues such as ambient temperature, osmolarity, or availability of nutrients induce specific gene expression programs and developmental transitions in many free-living prokaryotic and eukaryotic organisms. Life cycles of parasites are ordered series of genetically programmed developmental steps that are triggered by environmental cues. These signals are provided by distinct local environments within one host or between the host and a transmitting vector. Host defense mechanisms add another level of complexity to the regulatory mechanisms required for establishment of a stable hostparasite interaction or for progression in the life cycle (Combes and Morand 1999).

\section{Control of stage differentiation}

Here we provide novel insights into cold-induced molecular and phenotypic changes in mammalian blood stages of the flagellate $T$. brucei. We propose a comprehensive model for induction of development of the parasite to the procyclic insect stage. The model (see Fig. 8) incorporates three hitherto unexpected observations and our advance in understanding the hierarchy and mutual dependence of events:

1) A temperature shift from $37^{\circ} \mathrm{C}$ to $20^{\circ} \mathrm{C}$, termed cold shock, induces immediate and reversible expression of the insect-stage-specific EP procyclin surface protein in slender- and stumpy-stage bloodstream trypanosomes via a post-transcriptional mechanism.

2) A developmentally regulated surface protein trafficking and sorting control mechanism, termed surface access control, restricts EP from surface exposure in the proliferating slender cells, but allows surface routing in the cell cycle-arrested stumpy cells.

3) In stumpy (but not slender) cells, the cold shock elicits up to 1000 -fold increased sensitivity to cis-aconitate or citrate, compounds that are known to induce in vitro differentiation to the procyclic stage, but only when administered at very high concentrations (Brun and Schonenberger 1981; Czichos et al. 1986; Overath et al. 1986).

Three levels of control (Fig. 8) are integrated for differentiation to occur: temperature sensing, the receptive state of the stumpy cell, and citrate/cis-aconitate sensing. The discovery of developmentally regulated surface

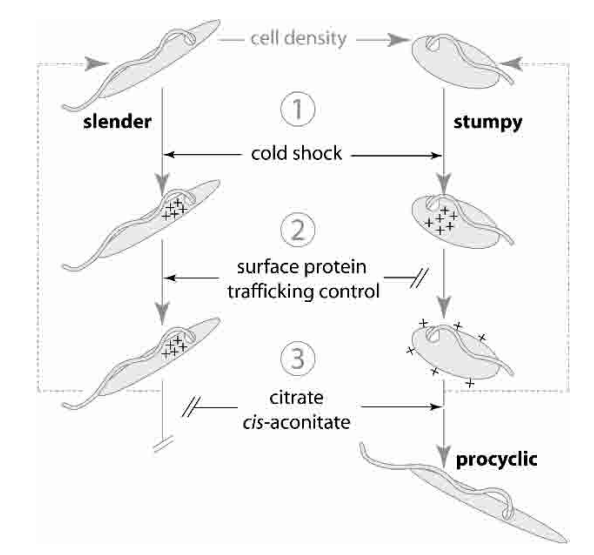

Figure 8. Model for the mechanisms regulating differentiation of bloodstream form trypanosomes to the procyclic stage. Large gray arrows indicate transitions between defined developmental or functional states. Additional dashed arrow lines indicate reversibility of the respective transitions. Small black arrows indicate the action of environmental cues (1), (3), or checkpointlike control (2). Crosses symbolize surface proteins (including EP and the putative citrate receptor) up-regulated by cold shock. The model does not exclude the participation of intracellular cold-induced proteins. 
access control provides an attractive new interpretation for the fact that only stumpy bloodstream trypanosomes are able to undergo efficient, fast, and synchronous differentiation in culture (Ziegelbauer et al. 1990; Rolin et al. 1993; Matthews and Gull 1994; Vassella and Boshart 1996; Tasker et al. 2000) and in tsetse (Vickerman 1965). The cold-inducible dramatic increase in the cis-aconitate/citrate sensitivity and the high stereochemical specificity of these inducing compounds (isocitrate or trans-aconitate are inactive) (see Results; Czichos et al. 1986) suggest a mode of action that involves specific binding. Biochemical experiments support an argument against significant citrate permeation into the cell (Hunt et al. 1994), although they could not firmly rule out an intracellular target. Recently, however, we have used inducible expression of a heterologous citrate synthase and gene deletion of aconitase (van Weelden et al. 2003) to manipulate intracellular citrate levels and have documented that citrate can only induce differentiation if it sees the outer cell surface of trypanosomes (M. Fast and M. Boshart, in prep.). Hence, we postulate that cis-aconitate- or citrate-mediated differentiation requires coldshock-induced expression or activation of a surface receptor. The striking correlation of EP surface routing and cis-aconitate/citrate sensitivity in slender- versus stumpy-form trypanosomes is an independent argument in favor of citrate sensing via a surface protein. Since overexpression of EP at $37^{\circ} \mathrm{C}$ did not render stumpy-form cells hypersensitive to cis-aconitate/citrate, the putative receptor must be a distinct entity.

There is a strict order of events during differentiation: cold shock provides "out of homeotherm" information and reversibly induces the major surface protein EP together with the putative receptor for citrate and cisaconitate. However, surface exposure of those proteins depends on previous cell cycle arrest and differentiation of slender to stumpy bloodstream form cells. Thus, the order of events in the life cycle appears to be maintained by virtue of a checkpoint-like mechanism acting via surface access control. Independent evidence that stumpyform cells are an obligatory stage in the life cycle has been discussed in depth in Matthews et al. (2004). According to several markers including VSG shedding, kinetoplast repositioning, reentry into the cell cycle, and expression of the stage-specific microtubule-binding protein CAP5.5 (Overath et al. 1983; Rolin et al. 1993; Matthews and Gull 1994; Matthews et al. 1995; HertzFowler et al. 2001), cold-shocked stumpy cells appear to be frozen in a distinct predevelopmental phase that normally persists for just $2 \mathrm{~h}$, during which both VSG and procyclin coexist within a mixed surface coat. Reversibility (indicated by a dashed line in Fig. 8) does even allow operating the temperature shift several times on the same population of cells (data not shown). Commitment to differentiation requires an additional signal, here cis-aconitate or citrate. In the absence of this signal, differentiation is an inefficient and asynchronous process that can only be selected for by cell culture conditions that favor procyclic trypanosomes.

Our model is perfectly compatible with the literature on trypanosome differentiation (for review, see Matthews et al. 2004). For example, slender cells are known to be refractory to cis-aconitate and citrate (Ziegelbauer et al. 1990; Tasker et al. 2000; D. Hedges and M. Boshart, unpubl.). Intracellular retention in slender cells of a putative receptor coregulated with EP accounts for this observation (see Fig. 8). Also, the efficient differentiation of stumpy trypanosomes in $6 \mathrm{mM}$ cis-aconitate at $27^{\circ} \mathrm{C}$ and even at $37^{\circ} \mathrm{C}$ (Fig. 7A; Matthews et al. 1995; D. Hedges and $\mathrm{M}$. Boshart, unpubl.) merely indicates that administration of unphysiologically high concentrations of cisaconitate can bypass the requirement for cold-shock-mediated sensitization.

\section{Developmentally regulated trafficking of EP}

Cold shock-induced expression of the insect-stage marker EP in slender and stumpy bloodstream-stage trypanosomes uncovered a striking difference in localization of this GPI-anchored surface protein in the two bloodstream stages. In stumpy cells EP is routed to the plasma membrane and is inserted into the VSG coat. In contrast, slender-form cells accumulate EP within the endocytic compartment, and no trace of EP is detectable on the pellicular surface. Nevertheless, the total EP expression levels in cold-shocked slender and stumpy cells are very similar. This is also reflected by similar estimates of the half-life of an EP:GFP fusion protein on the surface and in the endocytic compartment. The developmentally regulated trafficking of EP was also seen in transgenic trypanosomes overexpressing EP in the bloodstream stages at $37^{\circ} \mathrm{C}$. Thus, surface access control is independent of a cold shock. This novel mode of sorting of GPI-anchored proteins adds an additional level to developmental regulation of EP and likely other proteins. Cell surface access control may act as a safeguard to prevent exposure of invariant surface proteins in proliferating slender cells. Recognition by the immune system of an invariant surface protein would be detrimental for the parasite. Indeed, we found other trypanosomal (transferrin receptor) and heterologous (e.g., truncated VSG, scrapie prion) GPI-anchored proteins being equally restricted from the slender cell surface, but efficiently routed to the stumpy cell surface (M. Engstler and G. Cross, unpubl.; M. Engstler, in prep.). The perfect colocalization of EP with recycling VSG in the endocytic compartment suggests that this mechanism is part of the sorting events that concentrate VSG and keep the surface coat homogeneous (Grunfelder et al. 2002, 2003; Engstler et al. 2004). It seems possible that such a retention mechanism also exists for transmembrane proteins. The tartrate-sensitive histidine acid phosphatase (TbMBAP1), a type I transmembrane protein, is restricted to endosomes and is absent from the cell surface in slender cells. In stumpy trypanosomes, the protein is routed to the flagellar cell surface (F. Weise, K. Bopp, C.G. Grünfelder, N. Heddergott, P. Overath, and M. Engstler, in prep.; M. Engstler, unpubl.). Together, this suggests general slender-stage-specific mechanism(s) of trafficking control. 


\section{Post-transcriptional thermoregulation of EP}

The developmental regulation of EP procyclin expression is controlled at multiple levels (Hotz et al. 1998). Transcription in the slender bloodstream stage is five- to 10 -fold lower than in procyclic trypanosomes. Sequences in the $3^{\prime}$ untranslated region (UTR) induce rapid degradation of part of the RNA, adding an 11-fold post-transcriptional down-regulation of mRNA (Furger et al. 1997; Hotz et al. 1997). The same 3'-UTR sequences inhibit translation at least 10 -fold. Together this results in at least 1000-fold repression of procyclins in bloodstream-stage trypanosomes. Here we show that most of this repression is reversibly relieved by a cold-shock-induced mechanism that is dominant over the temperature-independent developmental control of expression. From a series of reporter constructs and transgenic cell lines, we conclude that cold-shock-induced EP gene expression is independent of (1) chromosomal context, (2) a particular promoter, (3) the procyclin 5 '-UTR, or (4) the EP coding sequence. Obviously, transcriptional control is not involved, whereas the EP $3^{\prime}$-UTR is sufficient to mediate more than 10-fold EP-specific cold response. In addition, direct evidence is provided for increased EP mRNA stability upon cold induction. The above 10 -fold gene-specific induction is on top of a three- to sixfold global cold induction that was recorded for all reporter constructs, including those with heterologous $3^{\prime}$-UTRs from tubulin, actin, or aldolase. We did not further investigate this effect, which might be due to a generally lower mRNA turnover at lower temperature. Comparison of cold-induced RNA and protein levels (Fig. 3) indicated a combined effect on EP RNA stability and translation efficiency, as commonly found in T. brucei (Clayton 2002). Deletion analysis showed that the putative cold-shock-sensing element is located between positions 173 and 297 of the EP1 3'-UTR. This excludes the conserved U-rich 26-mer (positions 134-159) that is in a single-stranded conformation (Drozdz and Clayton 1999) and is important for developmental regulation (Hotz et al. 1997; Schurch et al. 1997). Neither loop I nor loop II (harboring the 26-mer) of the calculated secondary structure model (Fig. 2B) is important for cold induction. Loop III includes a conserved 16-mer stem-loop that enhances translation in the procyclic stage by an unknown mechanism, but the activity of this element depends on the 26-mer (Furger et al. 1997), which is not important for cold induction (see above). The region between the 26mer and the 16-mer (positions 159-197) has been shown to contribute (14-fold) to developmental regulation (Hotz et al. 1997). Cold induction seems to target both mRNA stability and translation, but how it antagonizes the temperature-independent regulatory mechanisms remains to be investigated.

\section{A cold shock in the tropics?}

Is the differentiation model that we postulate applicable to the real in vivo situation, that is, differentiation in the midgut of a free-living tsetse that had a recent bloodmeal on an infected mammalian host? The large $\Delta T$ of $>15^{\circ} \mathrm{C}$ that needs to be sensed to induce EP expression and cisaconitate/citrate sensitivity is very "safe" to prevent invariant surface protein exposure in the mammalian host but nevertheless is surprisingly high in a tropical environment. Tsetse distribution is limited mainly by climatic determinants (Hendrickx et al. 2001), and flies change habitats in a season-dependent manner, favoring, for example, the cooler riverine woodlands during the hot season (Williams et al. 1990; Rogers et al. 1996; Van den Bossche and De Deken 2002). Furthermore, tsetse show a strict diurnal activity pattern and tend to rest during the day in cool refuges (Makumi et al. 1998; Torr and Hargrove 1999). The combination of available GIS data with an index of Land Surface Temperature (summarized in Rogers 2000) confirms that $T$. brucei, in fact, will experience cold shock conditions, latest during the first night after ingestion by the tsetse.

The in vivo significance of the temperature gradient is also suggested by the very rapid initial cell proliferation only seen when induction of differentiation includes a cold shock. The initial boost of proliferation was independent of cell density and of the amount of cis-aconitate added. The tsetse has evolved an efficient defense system against trypanosome invasion (Welburn and Maudlin 1999|, and only a very limited number of trypanosomes are taken up with the tsetse's bloodmeal (Vickerman et al. 1988). Thus, a rapid initial proliferation rate and rapid exchange of surface proteins is likely to be of vital importance for the establishment of a tsetse midgut infection.

Because cis-aconitate and citrate induce differentiation in the micromolar range in cold-shocked stumpy trypanosomes, these compounds can, for the first time, be discussed as candidates for natural inducers. Indeed, homogenates of tsetse after their first bloodmeal have been reported to contain $15 \mu \mathrm{M}$ of citrate (Hunt et al. 1994), a concentration sufficient to commit coldshocked stumpy trypanosomes to differentiation. The possibility remains that cis-aconitate and citrate are mimics of a yet-unidentified compound or activation mechanism in the tsetse. Nevertheless, the synergism and hierarchical order of two environmental cues seems to guarantee differentiation and rapid proliferation at exactly the right time, when the trypanosomes are ingested by the tsetse.

\section{Materials and methods}

\section{Trypanosomes}

Throughout this study T. brucei strains 427, variant MITat 1.2 (Cross and Manning 1973), and AnTat 1.1 (Delauw et al. 1985) were used. For T7-polymerase-driven protein expression the transgenic T. brucei clone 13-90 (Wirtz et al. 1999) was used. Culture conditions and transfection protocols are detailed in Vassella et al. (2001b) and McCulloch et al. (2004). Bloodstreamstage trypanosomes were grown in HMI-9 medium (Hirumi and Hirumi 1989). Differentiation to the procyclic insect stage and cultivation of procyclic trypanosomes was done in DTM-medium (Overath et al. 1986). Pure populations of stumpy forms were obtained $5-6 \mathrm{~d}$ after plating $5 \times 10^{4}$ slender AnTat 1.1 on 
agarose plates (Vassella and Boshart 1996). For selection of recombinant trypanosomes, antibiotics were added $18 \mathrm{~h}$ posttransfection $(2 \mu \mathrm{g} / \mathrm{mL}$ neomycin or phleomycin for pG-constructs; $1 \mu \mathrm{g} / \mathrm{mL}$ phleomycin for pLew20 and derivatives; $5 \mu \mathrm{g} /$ $\mathrm{mL}$ phleomycin for $\mathrm{pL} 82 ; 20-50 \mu \mathrm{g} / \mathrm{mL}$ neomycin for $\mathrm{pES} 221 ; 5$ $\mu \mathrm{g} / \mathrm{mL}$ hygromycin for pTSA-Rib; $1 \mu \mathrm{g}$ of hygromycin for $\mathrm{pTub})$. Antibiotic-resistant recombinant trypanosome pools were obtained after 5-7 d and cloned by limiting dilution.

\section{Immunofluorescence and microscopic imaging}

For immunofluorescence, $1-2 \times 10^{7}$ cells were fixed in suspension in $2.5 \%$ paraformaldehyde, $0.05 \%$ glutaraldehyde for at least $2 \mathrm{~h}$ at $4^{\circ} \mathrm{C}$, washed twice in $5 \mathrm{~mL}$ of phosphate-buffered saline (PBS), and resuspended in $200 \mu \mathrm{L}$ of PBS, $1 \%$ BSA. To detect intracellularly localized proteins, fixation was done in the absence of glutaraldehyde. Permeabilization of trypanosomes was achieved by $15 \mathrm{~min}$ of incubation in $500 \mu \mathrm{L}$ of $0.1 \mathrm{M}$ $\mathrm{Na}_{2} \mathrm{HPO}_{4} / 1 \mathrm{M}$ glycine ( $\mathrm{pH} 7.2$ ), followed by $5 \mathrm{~min}$ of incubation in $1 \mathrm{~mL}$ of $0.05 \mathrm{M} \mathrm{Na}_{2} \mathrm{HPO}_{4} / 0.5 \mathrm{M}$ glycine/0.1\% Triton $\mathrm{X}-100$ $(\mathrm{pH} 7.2)$. To localize the endocytic compartment, live trypanosomes $\left(4 \times 10^{8}\right.$ cells $\left./ \mathrm{mL}\right)$ were incubated with $2.5 \mathrm{mg} / \mathrm{mL}$ Alexa Fluor 594 conjugated dextran (MW10,000, lysine fixable; Molecular Probes) for $5 \mathrm{~min}$ at $37^{\circ} \mathrm{C}$, followed by two washes in $\mathrm{TDB}$ at $0^{\circ} \mathrm{C}$ and fixation. Surface biotinylation of live cells was done with $1 \mathrm{mM}$ Sulfo-NHS-SS-biotin (Pierce) for $10 \mathrm{~min}$ at $0^{\circ} \mathrm{C}$. After 5 min at $37^{\circ} \mathrm{C}$, surface biotin was cleaved off by incubation in a glutathione-containing buffer (Engstler et al. 2004).

Image acquisition was performed with a motorized Zeiss Axiophot 2 wide-field microscope equipped with a Zeiss $63 \times / 1.4$ NA Oil DIC objective, a $1.0 \times-2.5 \times$ optovar, and a Princeton Instruments Micromax cooled $\left(-15^{\circ} \mathrm{C}\right)$ slow scan CCD camera (Kodak KAF-1400 CCD chip). For acquisition of 3D images, a PIFOC objective $z$-stepper was driven by the piezo-amplifier E662 LVPZT (Physik Instrumente). Living trypanosomes were transiently immobilized on an object cooling stage. The microscopic set-up was integrated and controlled using the scripting feature of the IPLab for Macintosh software (version 3.2; Scanalytics). Deconvolution of 3D images was done as described using the Huygens System software (version 2.1.8; Scientific Volume Imaging B.V.) (Grunfelder et al. 2002, 2003; Engstler et al. 2004). Quantitative 3D-colocalization analysis was conducted using the Imaris Surpass software (Bitplane) as described earlier (Engstler et al. 2004).

For quantitative fluorescence microscopy 10 images of randomly chosen, nonoverlapping areas of the specimen were acquired, segmented, and measured using an IPLab software script. For threshold segmentation the following limit criteria were applied: Segments touching the image border were ignored. Data sets with saturated intensity values were excluded. The minimum intensity value $\left(\mathrm{I}_{\mathrm{min}}\right)$ of the segment had to be $>25 \%$ of the image maximum intensity value $\left(\mathrm{I}_{\max }\right)$. Segments with an area $20 \%$ smaller or larger than the mean segment area were ignored. For quantification of cell surface fluorescence, only segments with an eccentricity value $>0.3$ were chosen. Interior holes were included in all segments. Finally, a segment ranking by mean intensity value classification $\left(\Sigma \mathrm{I}_{\mathrm{xy}} / \mathrm{N}\right)$ was performed to analyze whether more than one population of segments was detected in the data set. Final data are given as means $( \pm S D)$ of 200-300 segments.

\section{Flow cytometry}

Trypanosomes were fixed in 2\% paraformaldehyde/0.05\% glutaraldehyde for more than $2 \mathrm{~h}$ at $4^{\circ} \mathrm{C}$. Cell surface exposed procyclin was labeled with the monoclonal anti-EP antibody TRBP1/247 (Cedar Lane Laboratories). For detection of EP1:GFP a polyclonal rabbit anti-GFP serum (Clontech) was used. Incubation with primary antibodies was done in a 1:500 dilution for $2 \mathrm{~h}$ on ice. FITC-conjugated secondary antibodies (Dianova) were used at dilutions of 1:2000. Alternatively, the GFP fluorescence of EP1:GFP was measured directly. For the analysis, a FACS-Calibur flow cytometer (Becton Dickenson) was used as described (Vassella and Boshart 1996).

\section{Constructs and nucleic acid analysis}

Details of all constructs and their derivation are available online as Supplemental Material. Northern blot analyses were performed by standard procedures using random primed probes (details available as Supplemental Material) and were quantified by a PhosphorImager (Molecular Dynamics).

\section{SDS-PAGE and immunoblotting}

Total protein extracts were separated on $12 \%$ polyacrylamide gels and transferred to Immobilon-P (Millipore). Western blots were probed for GFP (1:300) and for procylin (1:500), respectively, with the primary antibodies also used for flow cytometry (see above). After incubation with horseradish peroxidase-conjugated second antibodies (Amersham Pharmacia), the blots were developed in SuperSignal substrate (Pierce) as described in the manufacturer's instructions. As loading control for Western blots an anti-paraflagellar rod (PFR) antibody was used at a dilution of 1:1000 (Deflorin et al. 1994). Protein levels were determined using the densitometric measurement features implemented in the IPLab 3.5 software (Scanalytics).

\section{Luciferase assay}

For measurement of luciferase activity, cells were harvested at a density of $5 \times 10^{5}$ cells $/ \mathrm{mL}$, washed in PBS, and lysed in 250 $\mathrm{mM}$ Tris-HCl (pH 7.8), $1 \mathrm{mM}$ EDTA, $1 \mathrm{mM}$ DDT, and $0.2 \%$ Saponin by three rapid freeze/thaw cycles. Following centrifugation at $10,000 \times \mathrm{g}$ for $10 \mathrm{~min}, 10-\mu \mathrm{L}$ aliquots of the supernatant (corresponding to $10^{5}$ cells) were added to $100 \mu \mathrm{L}$ of luciferase assay reagent $\left(20 \mathrm{mM}\right.$ Tris- $\mathrm{HCl}$ at $\mathrm{pH} 7.8,5 \mathrm{mM} \mathrm{MgCl}{ }_{2}$, $0.1 \mathrm{mM}$ EDTA, $33 \mathrm{mM}$ DDT, $270 \mu \mathrm{M}$ coenzyme A, $470 \mu \mathrm{M}$ luciferin, $530 \mu \mathrm{M} \mathrm{rATP}$ ), and glow-type luminescence was measured using a Lumat LB9501 luminometer (Berthold).

\section{Acknowledgments}

We thank Sabine Kaiser for expert technical assistance; Jay Bangs (University of Wisconsin, Madison), Mark Field (Imperial College, London), George Cross (Rockefeller University, New York), and Keith Gull (University of Oxford) for antibodies; Isabel Roditi (University Bern) for EP1 3'-UTR deletion constructs; and Luc Vanhamme and Etienne Pays (ULB, Brussels) for construct pTSArib. David Rogers (University of Oxford) gave advice on tsetse ecology. We are grateful to Mark Carrington (Cambridge University, UK) for advice and critical reading of the manuscript. We thank Christine Clayton (ZMBH, Heidelberg) and Elisabetta Ullu (Yale University, New Haven, CT) for discussion. Cordula Schulte zu Sodingen, Miriam van den Bogaard, and Mark Günzel (all of this laboratory) made construct pL20$\Delta$ UTR.Luc, the AnTat1.1 antiserum, and the AnTat1.1 90-13 cell line. This work was funded by a DKFZ fellowship to M.E. and grants from BMBF and Fonds der Chemischen Industrie to M.B.

\section{References}

Acosta-Serrano, A., Vassella, E., Liniger, M., Kunz Renggli, C., Brun, R., Roditi, I., and Englund, P.T. 2001. The surface coat of procyclic Trypanosoma brucei: Programmed expression 
and proteolytic cleavage of procyclin in the tsetse fly. Proc. Natl. Acad. Sci. 98: 1513-1518.

Aguilar, P.S., Hernandez-Arriaga, A.M., Cybulski, L.E., Erazo, A.C., and de Mendoza, D. 2001. Molecular basis of thermosensing: A two-component signal transduction thermometer in Bacillus subtilis. EMBO I. 20: 1681-1691.

Alexander, D.L., Schwartz, K.J., Balber, A.E., and Bangs, J.D. 2002. Developmentally regulated trafficking of the lysosomal membrane protein p67 in Trypanosoma brucei. J. Cell Sci. 115: 3253-3263.

Bangs, J.D., Uyetake, L., Brickman, M.J., Balber, A.E., and Boothroyd, J.C. 1993. Molecular cloning and cellular localization of a BiP homologue in Trypanosoma brucei. Divergent ER retention signals in a lower eukaryote. J. Cell Sci. 105: 1101-1113.

Barry, J.D. and McCulloch, R. 2001. Antigenic variation in trypanosomes: Enhanced phenotypic variation in a eukaryotic parasite. Adv. Parasitol. 49: 1-70.

Biebinger, S., Rettenmaier, S., Flaspohler, J., Hartmann, C., Pena-Diaz, J., Wirtz, L.E., Hotz, H.R., Barry, J.D., and Clayton, C. 1996. The PARP promoter of Trypanosoma brucei is developmentally regulated in a chromosomal context. Nucleic Acids Res. 24: 1202-1211.

Borst, P. 2002. Antigenic variation and allelic exclusion. Cell 109: $5-8$.

Brun, R. and Schonenberger, M. 1981. Stimulating effect of citrate and cis-aconitate on the transformation of Trypanosoma brucei bloodstream forms to procyclic forms in vitro. Z. Parasitenkd. 66: 17-24.

Clayton, C.E. 2002. Life without transcriptional control? From fly to man and back again. EMBO J. 21: 1881-1888.

Clayton, C.E., Fueri, J.P., Itzhaki, J.E., Bellofatto, V., Wisdom, G.S., Vijayasarathy, S., and Mowatt, M.R. 1990. Transcription of the procyclic acidic repetitive protein genes of Trypanosoma brucei. Mol. Cell. Biol. 10: 3036-3047.

Combes, C. and Morand, S. 1999. Do parasites live in extreme environments? Constructing hostile niches and living in them. Parasitology 119: S107-S110.

Cross, G.A. 1987. Eukaryotic protein modification and membrane attachment via phosphatidylinositol. Cell 48: 179-181.

- 1996. Antigenic variation in trypanosomes: Secrets surface slowly. Bioessays 18: 283-291.

Cross, G.A.M. and Manning, J.C. 1973. Cultivation of Trypanosoma brucei sspp. in semi-defined and defined media. Parasitology 67: 315-331.

Czichos, J., Nonnengaesser, C., and Overath, P. 1986. Trypanosoma brucei: Cis-aconitate and temperature reduction as triggers of synchronous transformation of bloodstream to procyclic trypomastigotes in vitro. Exp. Parasitol. 62: 283-291.

Deflorin, J., Rudolf, M., and Seebeck, T. 1994. The major components of the paraflagellar rod of Trypanosoma brucei are two similar, but distinct proteins which are encoded by two different gene loci. J. Biol. Chem. 269: 28745-28751.

Delauw, M.-F., Pays, E., Steinert, M., Aerts, D., van Meirvenne, N., and LeRay, D. 1985. Inactivation and reactivation of a variant-specific antigen gene in cyclically transmitted Trypanosoma brucei. EMBO J. 4: 989-993.

Donelson, J.E., Gardner, M.J., and El-Sayed, N.M. 1999. More surprises from Kinetoplastida. Proc. Natl. Acad. Sci. 96: 2579-2581.

Drozdz, M. and Clayton, C. 1999. Structure of a regulatory 3' untranslated region from Trypanosoma brucei. RNA 5: 1632-1644.

Engstler, M., Thilo, L., Weise, F., Grunfelder, C.G., Schwarz, H.,
Boshart, M., and Overath, P. 2004. Kinetics of endocytosis and recycling of the GPI-anchored variant surface glycoprotein in Trypanosoma brucei. J. Cell Sci. 117: 1105-1115.

Fang, J. and McCutchan, T.F. 2002. Thermoregulation in a parasite's life cycle. Nature 418: 742.

Field, H., Sherwin, T., Smith, A.C., Gull, K., and Field, M.C. 2000. Cell-cycle and developmental regulation of TbRAB31 localisation, a GTP-locked Rab protein from Trypanosoma brucei. Mol. Biochem. Parasitol. 106: 21-35.

Furger, A., Schurch, N., Kurath, U., and Roditi, I. 1997. Elements in the 3 '-untranslated region of procyclin messengerRNA regulate expression in insect forms of Trypanosoma brucei by modulating RNA stability and translation. Mol. Cell. Biol. 17: 4372-4380.

Grunfelder, C.G., Engstler, M., Weise, F., Schwarz, H., Stierhof, Y.D., Boshart, M., and Overath, P. 2002. Accumulation of a GPI-anchored protein at the cell surface requires sorting at multiple intracellular levels. Traffic 3: 547-559.

Grunfelder, C.G., Engstler, M., Weise, F., Schwarz, H., Stierhof, Y.D., Morgan, G.W., Field, M.C., and Overath, P. 2003. Endocytosis of a glycosylphosphatidylinositol-anchored protein via clathrin-coated vesicles, sorting by default in endosomes, and exocytosis via RAB11-positive carriers. Mol. Biol. Cell 14: 2029-2040.

Gull, K. 2003. Host-parasite interactions and trypanosome morphogenesis: A flagellar pocketful of goodies. Curr. Opin. Microbiol. 6: 365-370.

Hendrickx, G., Napala, A., Slingenbergh, J.H., De Deken, R., and Rogers, D.J. 2001. A contribution towards simplifying area-wide tsetse surveys using medium resolution meteorological satellite data. Bull. Entomol. Res. 91: 333-346.

Hendriks, E., van Deursen, F.J., Wilson, J., Sarkar, M., Timms, M., and Matthews, K.R. 2000. Life-cycle differentiation in Trypanosoma brucei: Molecules and mutants. Biochem. Soc. Trans. 28: 531-536.

Hertz-Fowler, C., Ersfeld, K., and Gull, K. 2001. CAP5.5, a lifecycle-regulated, cytoskeleton-associated protein is a member of a novel family of calpain-related proteins in Trypanosoma brucei. Mol. Biochem. Parasitol. 116: 25-34.

Hirumi, H. and Hirumi, K. 1989. Continuous cultivation of Trypanosoma brucei bloodstream forms in a medium containing a low concentration of serum protein without feeder cell layers. J. Parasitol. 75: 985-989.

Hotz, H.R., Hartmann, C., Huober, K., Hug, M., and Clayton, C. 1997. Mechanisms of developmental regulation in Trypanosoma brucei: A polypyrimidine tract in the $3^{\prime}$-untranslated region of a surface protein mRNA affects RNA abundance and translation. Nucleic Acids Res. 25: 3017-3026.

Hotz, H.R., Biebinger, S., Flaspohler, J., and Clayton, C. 1998. PARP gene expression: Control at many levels. Mol. Biochem. Parasitol. 91: 131-143.

Hunt, M., Brun, R., and Kohler, P. 1994. Studies on compounds promoting the in vitro transformation of Trypanosoma brucei from bloodstream to procyclic forms. Parasitol. Res. 80: 600-606.

Johansson, J., Mandin, P., Renzoni, A., Chiaruttini, C., Springer, M., and Cossart, P. 2002. An RNA thermosensor controls expression of virulence genes in Listeria monocytogenes. Cell 110: 551-561.

Kelley, R.J., Alexander, D.L., Cowan, C., Balber, A.E., and Bangs, J.D. 1999. Molecular cloning of p67, a lysosomal membrane glycoprotein from Trypanosoma brucei. Mol. Biochem. Parasitol. 98: 17-28.

Makumi, J.N., Green, C., and Baylis, M. 1998. Activity patterns in Glossina longipennis: A field study using different sam- 
pling methods. Med. Vet. Entomol. 12: 399-406.

Matthews, K.R. 1999. Developments in the differentiation of Trypanosoma brucei. Parasitol. Today 15: 76-80.

Matthews, K.R. and Gull, K. 1994. Evidence for an interplay between cell cycle progression and the initiation of differentiation between life cycle forms of African trypanosomes. J. Cell Biol. 125: 1147-1156.

Matthews, K.R., Sherwin, T., and Gull, K. 1995. Mitochondrial genome repositioning during the differentiation of the African trypanosome between life cycle forms is microtubule mediated. J. Cell Sci. 108: 2231-2239.

Matthews, K.R., Ellis, J.R., and Paterou, A. 2004. Molecular regulation of the life cycle of African trypanosomes. Trends Parasitol. 20: 40-47.

McCulloch, R., Vassella, E., Burton, P., Boshart, M., and Barry, J.D. 2004. Transformation of monomorphic and pleomorphic Trypanosoma brucei. Methods Mol. Biol. 262: 53-86.

McKean, P.G. 2003. Coordination of cell cycle and cytokinesis in Trypanosoma brucei. Curr. Opin. Microbiol. 6: 600-607.

Muñoz-Jordán, J.L., Davies, K.P., and Cross, G.A.M. 1996. Stable expression of mosaic coats of variant surface glycoproteins in Trypanosoma brucei. Science 272: 1795-1797.

Overath, P., Czichos, J., Stock, U., and Nonnengaesser, C. 1983. Repression of glycoprotein synthesis and release of surface coat during transformation of Trypanosoma brucei. EMBO $J$. 2: 1721-1728.

Overath, P., Czichos, J., and Haas, C. 1986. The effect of citrate/ cis-aconitate on oxidative metabolism during transformation of Trypanosoma brucei. Eur. J. Biochem. 160: 175-182.

Roditi, I. and Pearson, T.W. 1990. The procyclin coat of African trypanosomes. Parasitol. Today 6: 79-82.

Roditi, I., Schwarz, H., Pearson, T.W., Beecroft, R.P., Liu, M.K., Williams, R.O., and Overath, P. 1989. Procyclin gene expression and loss of the variant surface glycoprotein during differentiation of Trypanosoma brucei. J. Cell Biol. 108: 737-746.

Rogers, D.J. 2000. Satellites, space, time and the African trypanosomiases. Adv. Parasitol. 47: 129-171.

Rogers, D.J., Hay, S.I., and Packer, M.J. 1996. Predicting the distribution of tsetse flies in West Africa using temporal Fourier processed meteorological satellite data. Ann. Trop. Med. Parasitol. 90: 225-241.

Rolin, S., Paindavoine, P., Hanocq-Quertier, J., Hanocq, F., Claes, Y., Le Ray, D., Overath, P., and Pays, E. 1993. Transient adenylate cyclase activation accompanies differentiation of Trypanosoma brucei from bloodstream to procyclic forms. Mol. Biochem. Parasitol. 61: 115-125.

Sbicego, S., Vassella, E., Kurath, U., Blum, B., and Roditi, I. 1999. The use of transgenic Trypanosoma brucei to identify compounds inducing the differentiation of bloodstream forms to procyclic forms. Mol. Biochem. Parasitol. 104: 311-322.

Schurch, N., Furger, A., Kurath, U., and Roditi, I. 1997. Contributions of the procyclin $3^{\prime}$ untranslated region and coding region to the regulation of expression in bloodstream forms of Trypanosoma brucei. Mol. Biochem. Parasitol. 89: 109-121.

Seed, J.R. and Wenck, M.A. 2003. Role of the long slender to short stumpy transition in the life cycle of the African trypanosomes. Kinetoplastid Biol. Dis. 2: 3.

Seyfang, A., Mecke, D., and Duszenko, M. 1990. Degradation, recycling, and shedding of Trypanosoma brucei variant surface glycoprotein. J. Protozool. 37: 546-552.

Shinozaki, K., Yamaguchi-Shinozaki, K., and Seki, M. 2003. Regulatory network of gene expression in the drought and cold stress responses. Curr. Opin. Plant Biol. 6: 410-417.

Tasker, M., Wilson, J., Sarkar, M., Hendriks, E., and Matthews, K. 2000. A novel selection regime for differentiation defects demonstrates an essential role for the stumpy form in the life cycle of the African trypanosome. Mol. Biol. Cell 11: 1905-1917.

Torr, S.J. and Hargrove, J.W. 1999. Behaviour of tsetse (Diptera: Glossinidae) during the hot season in Zimbabwe: The interaction of micro-climate and reproductive status. Bull. Entomol. Res. 89: 365-379.

Van den Bossche, P. and De Deken, R. 2002. Seasonal variations in the distribution and abundance of the tsetse fly, Glossina morsitans morsitans in eastern Zambia. Med. Vet. Entomol. 16: $170-176$.

van Weelden, S.W., Fast, B., Vogt, A., van der Meer, P., Saas, J., van Hellemond, J.J., Tielens, A.G., and Boshart, M. 2003. Procyclic Trypanosoma brucei do not use Krebs cycle activity for energy generation. J. Biol. Chem. 278: 12854-12863.

Vassella, E. and Boshart, M. 1996. High molecular mass agarose matrix supports growth of bloodstream forms of pleomorphic Trypanosoma brucei strains in axenic culture. Mol. Biochem. Parasitol. 82: 91-105.

Vassella, E., Reuner, B., Yutzy, B., and Boshart, M. 1997. Differentiation of African trypanosomes is controlled by a density sensing mechanism which signals cell cycle arrest via the cAMP pathway. J. Cell Sci. 110: 2661-2671.

Vassella, E., Acosta-Serrano, A., Studer, E., Lee, S.H., Englund, P.T., and Roditi, I. 2001a. Multiple procyclin isoforms are expressed differentially during the development of insect forms of Trypanosoma brucei. J. Mol. Biol. 312: 597-607.

Vassella, E., Kramer, R., Turner, C.M., Wankell, M., Modes, C., van den Bogaard, M., and Boshart, M. 2001b. Deletion of a novel protein kinase with PX and FYVE-related domains increases the rate of differentiation of Trypanosoma brucei. Mol. Microbiol. 41: 33-46.

Vickerman, K. 1965. Polymorphism and mitochondrial activity in sleeping sickness trypanosomes. Nature 208: 762-766.

- 1985. Developmental cycles and biology of pathogenic trypanosomes. Br. Med. Bull. 41: 105-114.

Vickerman, K., Tetley, L., Hendry, K.A., and Turner, C.M. 1988. Biology of African trypanosomes in the tsetse fly. Biol. Cell 64: 109-119.

Welburn, S.C. and Maudlin, I. 1999. Tsetse-trypanosome interactions: Rites of passage. Parasitol. Today 15: 399-403.

Williams, B., Brightwell, R., and Dransfield, R. 1990. Monitoring tsetse fly populations. II. The effect of climate on trap catches of Glossina pallidipes. Med. Vet. Entomol. 4: 181-193.

Wirtz, E., Hartmann, C., and Clayton, C. 1994. Gene expression mediated by bacteriophage T3 and T7 RNA polymerases in transgenic trypanosomes. Nucleic Acids Res. 22: 3887-3894.

Wirtz, E., Hoek, M., and Cross, G.A. 1998. Regulated processive transcription of chromatin by T7 RNA polymerase in Trypanosoma brucei. Nucleic Acids Res. 26: 4626-4634.

Wirtz, E., Leal, S., Ochatt, C., and Cross, G.A.M. 1999. A tightly regulated inducible expression system for dominant negative approaches in Trypanosoma brucei. Mol. Biochem. Parasitol. 99: 89-101.

Xong, H.V., Vanhamme, L., Chamekh, M., Chimfwembe, C.E., Van Den Abbeele, J., Pays, A., Van Meirvenne, N., Hamers, R., De Baetselier, P., and Pays, E. 1998. A VSG expression site-associated gene confers resistance to human serum in Trypanosoma rhodesiense. Cell 95: 839-846.

Ziegelbauer, K., Quinten, M., Schwarz, H., Pearson, T.W., and Overath, P. 1990. Synchronous differentiation of Trypanosoma brucei from bloodstream to procyclic forms in vitro. Eur. J. Biochem. 192: 373-378.

Ziegelbauer, K., Stahl, B., Karas, M., Stierhof, Y.D., and Overath, P. 1993. Proteolytic release of cell surface proteins during differentiation of Trypanosoma brucei. Biochemistry 32: 3737-3742. 


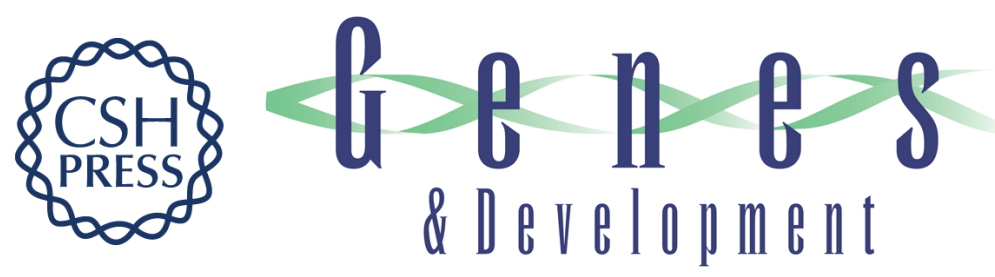

\section{Cold shock and regulation of surface protein trafficking convey sensitization to inducers of stage differentiation in Trypanosoma brucei}

Markus Engstler and Michael Boshart

Genes Dev. 2004, 18:

Access the most recent version at doi:10.1101/gad.323404

Supplemental http://genesdev.cshlp.org/content/suppl/2004/10/22/18.22.2798.DC1
Material

References This article cites 73 articles, 20 of which can be accessed free at: http://genesdev.cshlp.org/content/18/22/2798.full.html\#ref-list-1

License

Email Alerting Service

Receive free email alerts when new articles cite this article - sign up in the box at the top right corner of the article or click here.

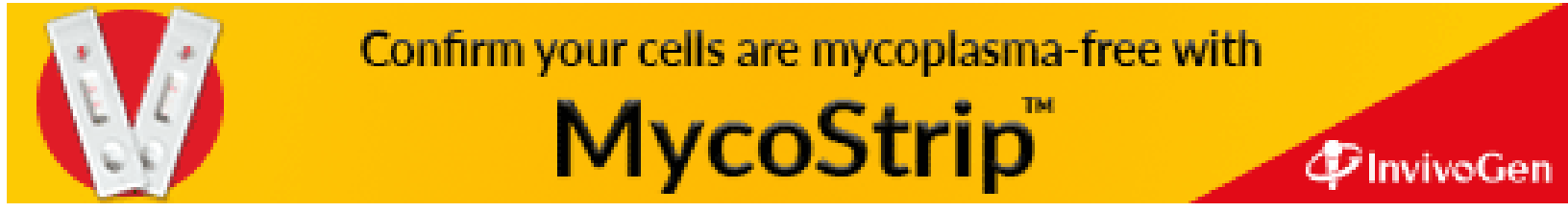

